\title{
Development of Traditional Creative Game Models to Improve Cognitive Ability in Early Childhood: A Preliminary Study
}

\author{
St. Maria Ulfah*, Arismunandar, Muhammad Arifin Ahmad \\ Department of Education, Universitas Negeri Makassar, Indonesia
}

Received June 16, 2020; Revised August 20, 2020; Accepted September 11, 2020

\section{Cite This Paper in the following Citation Styles}

(a): [1] St. Maria Ulfah, Arismunandar, Muhammad Arifin Ahmad, "Development of Traditional Creative Game Models to Improve Cognitive Ability in Early Chilhood: A Preliminary Study," Universal Journal of Educational Research, Vol. 8, No. 11, pp. 5106-5113, 2020. DOI: 10.13189/ujer.2020.081110.

(b): St. Maria Ulfah, Arismunandar, Muhammad Arifin Ahmad (2020). Development of Traditional Creative Game Models to Improve Cognitive Ability in Early Chilhood: A Preliminary Study. Universal Journal of Educational Research, 8(11), 5106-5113. DOI: 10.13189/ujer.2020.081110.

Copyright $\bigcirc 2020$ by authors, all rights reserved. Authors agree that this article remains permanently open access under the terms of the Creative Commons Attribution License 4.0 International License

\begin{abstract}
A critical aspect of children's development is cognitive aspect. To accumulate this aspect can be done by applying a traditional game model at the kindergarten level. The purpose of this study is to explore the needs of teachers in developing traditional creative play models to improve the cognitive aspects of children. The method used in this study is a qualitative method using interviews and observations as research instruments. There are several essential points in the findings of this study, namely (1) the cognitive abilities of children who are still lacking, (2) the lack of teachers who use play media in the form traditional games, (3) the learning process is still impressed in teacher-centred learning or learning that is dominated by the role of the teacher in the classroom, (4) many teachers still use conventional methods (lectures \& storytelling) so that only one-way responses occur, and (5) ) teachers need a game model for children that is interesting, fun, and not boring. These findings indicate the need for teachers to design traditional creative play models that can improve children's cognitive abilities.
\end{abstract}

Keywords Cognitive, Development, Traditional Creative Game

\section{Introduction}

Cognitive development is one of the important aspects to be developed in early childhood. Some of them are reading, writing, and arithmetic lessons. The phenomenon of parents sending their children to early childhood education programs generally hopes that when children enter elementary age, they are already proficient and clever in reading, writing and arithmetic.

Learning in kindergarten is learning with play patterns. Play is an essential characteristic of children's behaviour and is a natural learning tool for them [1] [2]. When playing, children learn various types of skills such as sharing expertise, understanding the perspectives of others, and patiently waiting to take turns [3].

The definition of learning, which is likened to meaning by playing, is also stated by several experts. According to Singer et al. [4], playing is a learning process. Furthermore, Smith et al. [5] also asserted that the main characteristics in playing are entertainment and having fun. That is, in the play activity, contained several aspects that are classified in the learning process for children.

Play activities can provide a context where children can achieve deep learning through the integration of intellectual, physical, moral, and spiritual values [6]. In addition, playing also provides a context for learning about their own culture. In other words, play can be interpreted as a useful tool for learning about the culture they have [7] [8]. Learning by playing also has a positive impact on aspects of child development, such as allowing children to commit to learning, physical development, and spiritual 
development [9].

Today, the types of games that are widely used by children are modern games. Mulyani [10] argues that modern games can be done because children are now in an age of technological sophistication. However, it is not wise to let the child stay quiet for too long on a television screen, in addition to damaging the eyes, the basic development of other children, such as cognition, emotions, social, language, and others will not develop optimally.

Modern games make children more individual creatures. Playing alone, winning happy alone, losing alone sad. Although there are games that can be played by two people, the actual interaction is not with the friend, but with the video game. Play store application data found that most of the traditional game-based games, such as traditional game applications lacking children's cognitive sharpening, because they rely more on fine motor playing fingers to win the game. In addition, playing games also has a less good impact on children's health, because the radicalization of the gadget itself is disrupting the health of the child's eyes.

In line with Mori in his research cited by Mulyani[10] that the impact of video games on brain activity adversely affects the health of human behaviour. Playing video games causes a decrease in forebrain activity which plays an important role in controlling emotions and activities, so that gamers quickly experience emotional changes, experience problems in social interactions, and decrease the power of concentration. In addition, playing video games causes a decrease in beta wave activity which is a long-term effect that continues even though gamers are not playing games. This is marked by an increase in the secretion of the hormone adrenaline, so that heart rate, blood pressure, and oxygen demand are boosted.

The results of a study by the Medical Faculty of Germany's Hanover University, as explained by Renggani quoted by Mulyani [10] have found that online games can cause a person to experience multiple personalities. This was obtained based on research on a woman who played online games every day for three months, by playing several different characters. Apparently, the imagination figures took over her personality so that the woman lost control of the control of her identity and social life.

Modern games, if not arranged properly, can make children lazy to learn, difficult to eat, and sleep on time. If the child is addicted to this modern game and he can spend hours and of course spend a lot of money. Instead, traditional games only require simple equipment by utilizing objects or objects in the surrounding environment, such as wood, stone, bamboo, and others. Traditional games provide learning to children about the importance of protecting the environment, respecting others, to love God. It is also close to nature so that it can contribute to increasing children's natural intelligence, as well as children's personal development.

Based on some of the adverse effects of the modern game, it is strongly recommended for teachers to apply traditional games for kindergarten children. Through this type of play, children are introduced to a variety of cultures of their own. Regular games must still be added to children, even though play activities are now dominated by modern games based on technology [11].

Several studies explore traditional games in improving cognitive aspects of children. Holis's study[12] show that children's play can improve cognitive as seen by the achievement of a percentage of the child's success rate increases so that the average results of the child's success rate exceed the minimum completeness criteria that have been set at $75 \%$. Likewise, the results of Muzakki's research [13]on the implementation of local culture-based early childhood learning revealed that at this time the young generation, especially children aged 4-7 years, is far from local religion and culture. These children are more familiar with foreign cultures than their own culture, for example in terms of games; children love the computer-based online games more than traditional games.

The traditional game of the Suru type from West Sumatra is also proven to have the potential to develop cognitive aspects of kindergarten children [14]. Besides, other types of traditional games from Indonesia were also researched by experts, and the results showed a positive impact on their cognitive aspects. Some examples of conventional games include cranks, clogs, and others [15][16].

From some of these descriptions, there is still no research that raises the traditional Mandar game from West Sulawesi. This condition is undoubtedly worrying about the development of children in the area because they are unable to identify various conventional games from their region. From the description above, researchers are interested in conducting preliminary studies to explore the needs of teachers in developing traditional Mandar creative games to improve children's cognitive aspects. The formulation of the problem in this study, namely how to describe the field needs of developing traditional creative play models in improving the cognitive abilities of young children?

\section{Literature Review}

\subsection{Cognitive}

One crucial aspect of child development is the cognitive aspect. Gunarti et al. [17] suggest that cognitive is a broad understanding of how to think and observe. Then according to Sujiono et al [18], cognitive or intellectual is a thought process in the form of the ability or power to connect an event with other events and the ability to judge and consider everything that is observed from the world around. On the other hand, cognitive is also interpreted as a domain of "thinking" that is closely related to the intellectual aspect 
[19].

Cognitive development in children is not only obtained from adults but also is achieved through their way of getting to know the environment and the world [20]. Cognitive aspects will continue to develop from the children's phase to the adult phase [21]. Thus, the need for special treatment is in developing the cognitive aspects of children.

Morrison [22] states that the cognitive development of preschoolers is in the preoperational stage in the development of intelligence. The characteristics of the preoperational stage are: (a) children develop the ability to use symbols, including language, (b) children have not been able to do operational thinking (operations are thoughts that can be reversed, (c) children are focused on one thought or idea, often outside other thoughts, (d) children have not been able to store memories and (e) children are egocentric.

Vigotsky in Sujiono [18]suggests that humans are born with a set of basic cognitive functions namely the ability to pay attention, observe and remember. In principle, a person acquires knowledge, stores it, then uses it or reproduces it, highly dependent on his thinking or cognitive abilities. Sujiono[18] suggested that Bloom's taxonomy is widely used to plan and evaluate learning activities so that children can develop their cognitive abilities fully. The hierarchical structure that identifies skills ranges from low to high levels. Of course, to achieve higher goals, low levels must be met first. Purpose of education according to Bloom is divided into three domains of intellectual abilities (intellectual behaviours) namely cognitive, affective and psychomotor.

The development of individuals underlies Bloom's Taxonomy, namely dimensions cognitive development. This cognitive domain consists of six-level, namely: (a) knowledge, (b) comprehension (understanding or perception), (c) application, (d) analysis (decomposition or elaboration), (e) synthesis (integration), and (f) evaluation (assessment) [18].

\subsection{Creative Traditional Game}

The term game comes from the basic word "play" which gets an affix. In the Big Indonesian Dictionary," play" is to do something pleasing (by using tools or not). Thus," game" is something that is used to play, things or things to be played, deeds are done in earnest, indifferent.

Drevdahl in Hurlock[23] argues that creativity is a person's ability to produce any composition, product or idea that is new, and previously unknown to its maker, whereas according to Einon[24] creative people are people who are approaching things in a new way. Not what they do, but the way they do it.

According to Yunus in Mulyani [10] explained that the traditional game is a product of the culture of society, which comes from very old times, which has grown and lived until now, with supporting communities consisting of young and old men, women, rich-poor, noble people, with no difference. The learning process has two very important elements, namely learning methods and media. These two aspects are interrelated. The choice of one particular learning method will affect the appropriate type of learning media.

Beaty [25] suggested that Piaget and Vygotsky agreed that children form their knowledge through exploration games. They do this by playing with objects, people and ideas. Children use their sense of taste, touch, listener, vision, and controller. Therefore, children's play is a sensory exercise in learning to think.

Traditional games are not just entertaining devices, traditional games as games that are developed and played by children in the general public by absorbing all the wealth and wisdom of their environment in traditional games, all aspects of children's humanity are developed, creativity and enthusiasm for innovation are realized.

The traditional creative game in this study is the traditional Mandar tribe game that was developed, where previously the game makkabacciq was played by 2 players. Before starting, the game must be suited first, and then the first player to spread shells around a coconut shell put the shells into a coconut shell by using thumbs or makkace mandar term. If the shells cannot enter the coconut shell or insert 2 shells into the coconut shell hole, they will be replaced by player 2 . The development of this research is that the results of the shells successfully inserted will be linked to the concept of a number symbol, where the child takes a number card which corresponds to the number of shells that have been obtained.

The second game is the mamboi game, the development of this game is a tool used in the form of broken tiles replaced into flat stones which are painted and given numbers. The goal is that the child does not only arrange stones from large to small but can also sort numbers from 10 to 1 . Besides, the rules of the game that originally threw the ball at the opponent were removed because they were not educational.

The factors influence children's play, namely health, motor development, intelligence, gender, environment, socioeconomic status, the amount of free time and play equipment[23]. Freud in Sujiono[18] revealed that playing is not the same as working, but children consider playing as something serious. Early childhood does not distinguish between playing, studying and working. In general, children enjoy the game and will continue to do it wherever they have the opportunity, so playing is one way of early childhood learning because through play children learn about what they want to know and ultimately be able to recognize all the events that occur around them.

There are three main steps in the procedure of using media in learning that need to be followed, namely: 1) Preparation, 2) Implementation, and 3) Follow-up[26]. The learning method through play consists of three main steps, 
namely the pre-playing stage, the playing stage and the closing stage[27]. The steps of the Makkabacciq traditional creative game are as follows:

\section{a). Pre-game Stage}

The stages of play consist of two kinds of preparatory activities, namely the preparation of students in carrying out play activities and the preparation of traditional creative game media. Student preparation activities consist of: the teacher explains the purpose of play activities to students; the teacher prepares rules that must be followed in play activities; the teacher offers assignments to each child; the teacher makes clear what each child has to do in doing their work. Activities to prepare materials and equipment are needed, for example preparing traditional creative play media and materials needed.

\section{b). Play Stage}

The stages of this traditional creative game are as follows: a) The teacher introduces the traditional makkabacciq traditional creative media to be learned, b) The teacher explains how to use the makkabacciq traditional creative game, then the child is told to pick up 10 shells each, d) Children first suit to start the game, e) After that, the child tells the opponent to choose one of the shells to flick to put in the hole, f) The teacher motivates the child to count the number of shells obtained and connect them to the symbol of numbers, g) The use of this media is practiced for all learners.

\section{c). Closing Stage}

The concluding stage of the learning method starts playing consists of activities (a) attracting attention and arousing children's interest (b) connecting the child's experience in playing that has just been done with other experiences, for example at home (c) showing important aspects of work as a group (d) emphasizing the importance of cooperation.

It can be concluded that it is necessary to make various efforts to present play activities that are conducive to children's development. Parents and teachers need to understand the nature of play and games which include the meaning of the play, various types of games, good playing conditions, early childhood development and how to design play activities and educational play tools. Besides that, parents and educators should be able to play as a companion or 'friends' who play well for children, namely as a facilitator and motivator so that they can direct educational play activities.

\section{Materials and Methods}

\subsection{Research Method}

This research is a preliminary study of research \& development to design traditional creative play products to improve children's cognitive abilities. Thus, a suitable research method used in this preliminary study phase is a qualitative method. This method is a research method that aims to explore a particular phenomenon or event so as to produce a specific picture of what happened [28] [29]. From the results of this illustration, researchers can proceed to the next stage to design and test products that will be developed.

\subsection{Research Site \&Participants}

The location of this research was conducted in kindergarten Fathinah, Banggae District, Majene Regency, Indonesia. The subjects in this study were group B students (ages 5-6 years) in kindergarten Fathinah, Majene Regency. The implementation time is even semester in January to March 2020.

The selection of research locations in Fathinah Kindergarten, Majene Regency, is based on two things, namely (1) 5-6 years old children (group B) have had the maturity of thinking in exploring the world through stimulation provided by the teacher in play, (2) Because most of the students in Fathinah kindergartens come from families who have parents who work as traders and fishermen where they are busy with their work. Determination of participants like this is called by purposive sampling[29][30]. The use of purposive sampling technique aims to obtain a lot of information that can support and explain various research questions [31] [32].

In addition to the students, participants who were also involved in the study were three kindergarten teachers. In qualitative design, the participants involved are usually not too many. This is due to the nature of qualitative research which does not make generalizations. Too many participants can have an impact on research results that are only able to reach their surface area [33].

\subsection{Instruments}

\section{a. Semi-structured Interview}

One of the instruments used in this study was the interviews. This instrument is most commonly used by experts/researchers in qualitative research designs. This interview was aimed at Kindergarten teachers with the aim of exploring information about the obstacles and situations faced by the teachers in relation to the use of traditional games.

This type of interview was chosen and used in this research semi-structured interview. Specifically, this type of interview was used to explore more deeply about the phenomena or events of the participants. The participants were asked questions and then asked to answer based on arguments and opinions without being limited by choice of answers [34]. In addition, the use of semi-structured 
interviews is also useful for researchers to add questions in the process of elaboration and clarification [30] [35].

Furthermore, the interview process is carried out in a confined space with the aim of reducing and minimizing the potential for outside interference [36]. Researchers record using a voice tape recorder which then the data are transcribed into a computer device [37] [38]. The duration of the interview for each participant is limited to a maximum of 60 minutes.

\section{b. Observation}

The next instrument used in this study is observation. The observation process is carried out before the process of designing a product that aims to find various obstacles and problems that occur in the field. Observation technique is a specific approach using the researcher's senses to collect data about a particular phenomenon, behaviour, or subject [39]. Furthermore, this technique can also be regarded as a data collection technique that seems relaxing but remains clinically guided [40].

\subsection{Data Analysis}

Data obtained through semi-structured interviews were then analyzed using content analysis techniques. This type of technology is widely recommended by experts when analyzing data from qualitative research [41] [42] [28]. The purpose of using content analysis techniques is to obtain associations and new concepts that can explain the data collected [43].

\section{Results}

\subsection{Interview Result}

The interview was conducted by researchers on Monday, February 29, 2020, by asking the following questions:

(1) How long have you been teaching kindergarten children?

(2) What are your challenges and obstacles to teaching kindergarten children?

(3) What method do you use in teaching kindergarten children?

(4) Have you ever applied traditional play patterns in teaching?

(5) Should a book be developed that reviews traditional game models that are modified to improve the cognitive aspects of children?

The results of the interviews showed that 3 Fathinah Kindergarten teachers had long taught with five years of service and above. This long teaching time certainly provides a lot of experience for teachers in managing classes. Teacher "A" states that "I have been teaching 5 years ago and these years provide valuable experience in guiding and directing children".
Regarding the challenges in teaching kindergarten children, the teachers gave almost uniform answers. The children's phase, which is the play phase, is considered necessary to give extra attention because of the nature of the children who are sometimes very difficult to control. This is in line with the statement of teacher " $\mathrm{C}$ " which states, "Early childhood is indeed the time to play. Well, here is the challenge of a kindergarten teacher in developing games that are interspersed with activities that can stimulate cognitive, affective, and psychomotor aspects ".

The results of interviews with kindergarten teachers discussing the method of play they applied showed diversity. That is, each teacher applies a different method of learning and playing. The interview snippet can be seen in the following table.

Table 1. Interview snippets about learning methods

\begin{tabular}{cl}
\hline Teacher name & \multicolumn{1}{c}{ Interview footage } \\
\hline A & $\begin{array}{l}\text { "I more often use the method of storytelling } \\
\text { when teaching children. For me, this method is } \\
\text { very helpful in attracting their attention! " }\end{array}$ \\
& "It's been a long time since I used the singing and \\
& performance strategies. I think this method is \\
B & more effective in training children in their \\
& psychomotor and cognitive fields. " \\
\hline C & $\begin{array}{l}\text { learning media which is widely available in the } \\
\text { learning environment" }\end{array}$ \\
\hline
\end{tabular}

The majority of teachers have never applied the traditional game model in teaching kindergarten children. Instead, they tend to use games that are classified as modern. Teacher " $\mathrm{C}$ " states that "I often use modern game models rather than traditional games because I consider that they are a generation that is advanced and close to technology". Likewise, with the other two teachers, they also never applied the traditional game model in teaching.

The final question in this interview tries to explore the opinions and arguments of the teachers about the importance of whether or not developing a traditional creative game model. All three participants have the same answer that traditional game models are needed with various arguments. The following table shows a snapshot of the participants' answers.

Table 2. Interview footage of the importance of traditional game models

\begin{tabular}{cl}
\hline Teacher name & \multicolumn{1}{c}{ Participant answer snippet } \\
\hline & "The need for traditional creative game models \\
A & from the Mandar area so that children can get to \\
& know the types of traditional local games such as \\
& Makkabaciq and Mamboi" \\
& "I think it is important to develop a traditional \\
& creative game model so that children not only \\
B & recognize modern games but also recognize \\
& traditional games from their own area" \\
& "Traditional game models are needed right now \\
& so that children do not forget their own culture. \\
C & One of them that can be applied is the \\
& Makkabaciq game " \\
\hline
\end{tabular}




\subsection{Observation Results}

Researchers made observations on Wednesday, 28 February 2020, in Fathinah Kindergarten, and the results showed that children lack understanding about traditional games. This is caused by the erosion of Mandar cultural values that has begun to be forgotten and the lack of interest of children to know various Mandar cultures that they did not know before. This happens because of the diminishing traditionality of the child's playing and is slowly being abandoned. In fact, today, children no longer know the names of these games.

Also, observations show that there are very few teachers who use traditional playing media in the learning process of kindergarten children. Teachers tend to use media that are already available and widely available in the market. This condition positively affects the learning process and is also considered to be less stimulating and fostering children's cognitive abilities.

Other observations show that the level of activity of children is very minimal in class. The children seemed passive and only listened to the explanations from the teachers. On several occasions, children were seen actively asking and responding to teachers, but still on a small scale. This, of course, affects the level of child development, one of which is on the cognitive aspects.

Based on the phenomena that occur above that the inability of early childhood to recognize traditional Mandar tribe games is a challenge for teachers to introduce traditional Mandar games through traditional creative games that have been modified and following the standard level of achievement of children's development in this age 5-6 years so that children will get to know the culture. 2 traditional creative games are used, namely the Makkabacciq game and the Mamboi game

\section{Discussion}

The traditional creative game model is a child-centred learning model, with this learning model, the introduction of traditional games will make it easier for children to understand their own local culture. In the introduction of culture from an early age, it will give a sense of pride in children and their love of their own culture so that it will form a more dignified personality. Therefore, the traditional creative learning model of learning is very efficient for developing children's cognitive abilities because in this process children are more active in their role than teachers [44][45][46].

Seeing the characteristics of children aged 5-6 years where the age is the age of play, and then what the researchers and the teacher at Fathinah Majene Kindergarten designed a learning method which was packaged in the form of a game. Based on observations and interview, learning methods that promote and preserve the local culture of the Mandar community are packaged in the form of games, namely Makkabacciq and Mamboi. Research using traditional games from different regions in Indonesia was also carried out by several researchers, namely the popular game of Suru, West Sumatra [14], Engklak [16], and Clogs and other games [15].

Traditional games have to be introduced early on to children. This is considered necessary because each child must be equipped with cultural values around them that can be identified from the traditional game. Although a game is supposed to contain the amount of hedonism, it is undeniable that through the game, many other benefits can also be obtained [6]. Besides cognitive aspects, traditional games have also been stated to have benefits for the development of self-confidence \& intelligence in mathematical logic [47], character development [48], prosocial behaviour [49], and the development of motor children [50].

\section{Conclusions}

This study is the initial phase in developing traditional creative play models in developing cognitive aspects of children. This study seeks to explore the level of needs of kindergarten teachers in integrating regular original games into the learning process and play for kindergarten children. Based on observations and interview results, it can be concluded that the cognitive aspects of children in kindergarten are still low and they do not recognize any traditional games, especially the conventional game of the Mandar area. Thus, we need a creative traditional game model from Mandar area to be used in the learning process, one of which is the game Makkabaciq and Mamboi. Both of these popular games are considered able to improve the cognitive aspects of kindergarten children and increase children's insights about regular Mandar games.

\section{REFERENCES}

[1] A. Anning and A. Edwards, Promoting Children's Laerning from Birth to Five Developing The New Easily Years Professional. Maidenhead: Open University Press, 2006.

[2] D. P. Fromberg and D. Bergen, "Introduction," in Play from Birth to Twelve: Contexts, Perspective and Meanings, D. P. Fromberg and D. Bergen, Eds. New York: Routledge, 2006.

[3] R. Devries, "Games with Rules," in Play from Birth to Twelve, 2nd Editio., D. P. Fromberg and D. Bergen, Eds. Abingdon, Oxon: Routledge, 2006.

[4] D. G. Singer, R. M. Golinkoff, and K. Hirsh-Pasek, Playing = Learning: How Play Motivates and Enhance Children's Cognitive and Social-emotional Growth. New York: Oxford University Press, 2006.

[5] P. K. Smith and A. Pellegrini, "Learning through Play," Encycl. Early Child. Dev., vol. June, pp. 1-6, 2013. 
[6] A. Aypay, "Investigating The Role of Traditional Children's Games in Teaching Ten Universal Values in Turkey," Eurasian J. Educ. Res., vol. 62, pp. 283-300, 2016.

[7] J. W. Neuliep, Intercultural Communication: A Cintextual approach. Thousand Oaks, CA: Sage Publications, 2012.

[8] H. Tulak, H. Wijaya, S. N. Rante, N. Nurmadiah, and H. Helaluddin, "The intercultural competence in education era 4.0: A learning strategy for students of elementary school in indonesia," in Proceedings of The 1st International Conference of Science and Technology in Elementary Education, 2019, pp. 1-9.

[9] A. Y. Kolb and D. A. Kolb, "Learning to Play, Playing to Learn A Case of A Ludic Learning Space," J. Organ. Chang. Manag., vol. 23, no. 1, pp. 26-50, 2010.

[10] N. Mulyani, Super Asik Permainan Tradisional Anak Indonesia. Yogyakarta: Diva Press, 2016.

[11] M. R. Cecilia, D. Di-Giacomo, and P. Vittorini, "Influence of Gaming aActivities on Cognitive Performance," $A d v$. Intell. Syst. Comput., vol. 374, 2015.

[12] A. Holis, "Belajar melalui Bermain untuk Pengembangan Kreativitas dan Kognitif Anak Usia Dini," J. Pendidik UNIGA, vol. 10, no. 1, pp. 23-37, 2016.

[13] M. Muzakki and P. Y. Fauziah, "Implementasi Pembelajaran Anak Usia Dini Berbasis Budaya Lokal di PAUD Full Day School," J. Pendidik. dan Pemberdaya. Masy., vol. 1, no. 2, pp. 39-54, 2015.

[14] S. Fauziah and D. Hastuti, "Modifikasi Permainan Tradisional Sumbar Suru untuk Mengembangkan Aspek Kognitif pada Kelompok B Anak Usia Dini,” J. Smart Paud, vol. 2, no. 1, pp. 47-53, 2019.

[15] U. Gustian, E. Supriatna, and E. Purnomo, "Efektifitas Modifikasi Permainan Tradisional dalam Pengembangan Physical Literacy Anak Taman Kanak-kanak," $J$. Keolahragaan, vol. 7, no. 1, pp. 23-33, 2019.

[16] D. A. Pertiwi, S. F. Fitroh, and D. Mayangsari, "Pengaruh Permainan Tradisional Engklek terhadap Perkembangan Kognitif Anak Usia 5-6 Tahun," J. PG-PAUD Trunojoyo J. Pendidik. dan Pembelajaran Anak Usia Dini, vol. 5, no. 2, pp. 86-100, 2018.

[17] W. Gunarti, L. Suryani, A. Muis, and N. Pratiwi, "Metode Pengembangan Perilaku dan Kemampuan Dasar Anak Usia Dini," Universitas Terbuka, 2016. [Online]. Available: https://www.pustaka.ut.ac.id/paud4401-metode-pengemban gan-perilaku-dan-kemampuan-dasar-anak-usia-dini/. [Accessed: 22-Jun-2020].

[18] N. Y. Sujiono, O. R. Zainal, and E. L. Tampiomas, "Metode Pengembanagan Kognitif," Universitas Terbuka, 2016. [Online]. Available: https://www.pustaka.ut.ac.id/lib/paud4 161-metode-pengembangan-kognitif/.

[Accessed: 22-Jun-2020].

[19] G. Kasilingam, M. Ramalingam, and E. Chinnavan, "Assessment of Learning Domains to Improve Student's Learning in Higher Education," J. Young Pharm., vol. 6, no. 1, pp. 27-33, 2014.

[20] H. P. Ginsburg, C. Greenes, and R. Balfanz, Big Math for Little Kids "Program Overview" Pasippany. New Jersey: Pearson Learning Group, 2003.
[21] N. Pierce, Digital Game-based Learning for Early Chilhood. Dublin, Ireland: Learnovate Centre, 2013.

[22] G. S. Morrison, Dasar-dasar Pendidikan Anak Usia Dini (PAUD), 5th Editio. Jakarta: Indeks, 2012.

[23] E. B. Hurlock, Perkembangan Anak. Jakarta: Erlangga, 2000.

[24] D. Einon, Permaianan Kreatif untuk Anak-anak. Batam: Karisua Publishing Group, 2004.

[25] J. J. Beaty, Observasi Perkembangan Anak Usia Dini, 7th Editio. Jakarta: Kencana Prenada Media Group, 2013.

[26] S. Suyanto and A. Jhad, Menjadi Guru Profesional: Strategi Meningkatkan Kualifikasi dan Kualitas Guru di Era Global. Jakarta: Esensi Erlangga, 2013.

[27] N. A. Wiyani and B. Barnawi, Konsep, Karakteristik, dan Implementasi Pendidikan Anak usia Dini. Yogyakarta: Ar-Ruzz Media, 2014.

[28] H. Helaluddin and H. Wijaya, Analisis Data Kualitatif: Sebuah Tinjauan Teori \& Praktik. Makassar: Sekolah Tinggi Filsafat Jaffray, 2019.

[29] J. W. Creswell, Qualitative Inquiry \& Research Design: Choosing among Five Approach. London: Sage, 2007.

[30] W. Percy, K. Kostere, and S. Kostere, "Generic Qualitative Research in Psychology," Qual. Rep., vol. 20, no. 2, pp. 7685,2015 .

[31] C. Teddlie and F. Yu, "Mixed Methods Sampling: A Typology with Examples," J. Mix. Methods Res., vol. 1, no. 1, pp. 77-100, 2007.

[32] I. J. A. Ubah and S. Bansilal, "Pre-service Mathematics Teachers' Knowledge of Mathematics for Teaching: Quadratic Functions," Probl. Educ. 21st Century, vol. 76, no. 6, pp. 847-863, 2018

[33] J. W. Creswell, Educational Research. New Jersey: Pearson Merril Prentice Hall, 2005.

[34] D. Wilkinson and P. Birmingham, Using Research Instruments: A Guide for Researchers. London: RoutledgeFalmer, 2003.

[35] K. H. Guthrie, "“Nothing is Ever Easy': Parent Perceptions of Intensity in Their Gifted Adolescent Children," Qual. Rep., vol. 24, no. 8, pp. 2080-2101, 2019.

[36] C. S. Josilowski, “Teachers' Perception of The home-school Collaboration: Enhancing Learning for Children with autism," Qual. Rep., vol. 24, no. 12, pp. 3008-3021, 2019.

[37] M. Q. Paton, Qualitative Research \& Evaluation Methods. Thousand Oaks: SAGE Publication Ltd, 2014.

[38] K. Lee, C. Ang, and G. Dipolog-ubanan, “"My First year in The University': Students'Expectations, Perceptions and Experiences," J. Soc. Sci. Res., vol. 14, pp. 3134-3145, 2019.

[39] K. B. Ameyaw, K. N. Ofori, B. Adjepong, and H. D. Assem, "Using Observational techniques as Assessment Instruments to Improve Learners' Performance at Nkawkaw, Ghana," IOSR J. Res. Method iin Educ., vol. 8, no. 6, pp. 87-96, 2018 
[40] M. K. Numale, J. Ohene, and A. K. Addison, Psychological Basis for Teaching and Learning. Winneba: University of Education, 2012.

[41] M. B. Miles and A. M. Huberman, An Expanded Sourcebook-qualitative Data Analysis. London: Sage Publications, 1994.

[42] A. Strauss and J. Corbin, Basics of Qualitative research: Grounded Theory Procedures and Techniques. Newbury Park: Sage, 1990.

[43] S. Yildiz and S. Gizir, "A Phenomenological Study of The Perceptions of Candidate Teachers about The Concepts of School, Teacher and Student in Their Dreams," Int. J. Instr., vol. 11, no. 2, pp. 309-324, 2018.

[44] R. E. Sulistyaningtyas and P. Y. Fauziah, "The Implementation of Traditional Games for Early Childhood Education," in Advance in Social Science, Education and Humanities Research/ 3rd International Conference on Current Issues in Education, 2019, no. 326, pp. 431-435.

[45] I. W. Widiana, I. N. Jampel, and I. P. Prawini, "The Effectiveness of Traditional Game-based Communication Learning Activity for Cognitive Process Dimension Learning Achievement," Cakrawala Pendidik., vol. XXXVII, no. 2, pp. 260-269, 2018.
[46] T. Vasileva-Stojanovska, M. Vasileva, T. Malinovski, and V. Trajkovik, "The Educational Prospects of Traditional Games as Learning Activities of Modern Students," Proc. Eur. Conf. Games-based Learn., vol. 2, no. October, pp. 746-759, 2014.

[47] A. Lestariningrum, "The Effects of Traditional Game 'Congklak' and Self-confidence towards Logical Mathematical Intelligence of 5-6 Years Children," J. Indria J. Ilm. Pendidik. Prasekolah dan Sekol. Awal, vol. 3, no. 1, pp. 13-22, 2018.

[48] S. Supeni, L. Hakim, and Jumintono, "Strengthening Character Education of Early Childhood through Javanese Traditional Game d=Dakon," Int. J. Recent Technol. Eng., vol. 7, no. 6, pp. 243-249, 2019.

[49] N. L. M. A. Dewi, Y. Suryati, F. Rudhiati, and H. S. Mediani, "The Effect of Traditional Game of Magoak-Goakan to The Prosocial Behavior among Preschool Children (5-6 Years Old) At Maria Fatima Kindergarten Jembrana Bali," IOSR J. Nurs. Heal. Sci., vol. 7, no. 5, pp. 1-7, 2018.

[50] A. Aneka and A. Rahmatika, "The Benefits of Traditional Game 'Clogs' to Develop Early Childhood's Rough Motoric," Elem. J. Ilm. Pendidik. Dasar, vol. 5, no. 1, pp. 107-115, 2019. 